\title{
Akuaponik sebagai Sistem Pemanfaatan Limbah Budidaya Ikan Lele di Desa Kalijaran
}

\author{
Murni Handayani ${ }^{1}$, Cahya Vikasari ${ }^{2}$, Oto Prasadi ${ }^{3}$ \\ ${ }^{1}$ Jurusan Teknik Mesin, Politeknik Negeri Cilacap \\ 2 Jurusan Teknik Informatika, Politeknik Negeri Cilacap \\ ${ }^{3}$ Jurusan Teknik Mesin, Politeknik Negeri Cilacap \\ Email: murnihandayani@pnc.ac.id
}

\begin{tabular}{|c|c|}
\hline Informasi Artikel: & ABSTRAK \\
\hline $\begin{array}{l}\text { Received: } \\
27 \text { Maret } 2020 \\
\text { Accepted: } \\
05 \text { April } 2020 \\
\text { Available: } \\
08 \text { Mei } 2020\end{array}$ & $\begin{array}{l}\text { Kelompok tani ikan Mina Jaya Desa Kalijaran mempunyai potensi dalam } \\
\text { memproduksi sayur-sayuran dengan menggunakan sistem akuaponik, hal } \\
\text { ini karena didukung oleh limbah budidaya ikan lele yang melimpah. } \\
\text { Pemanfaatan limbah budidaya ikan lele masih belum maksimal. } \\
\text { Pemanfaatan limbah budidaya ikan lele oleh sebagian besar anggota } \\
\text { kelompok tani ikan Mina Jaya Desa Kalijaran belum mengarah untuk } \\
\text { menghasilkan produk pertanian berupa sayur-sayuran dengan sistem } \\
\text { akuaponik. Tujuan dari kegiatan pemberdayaan kelompok tani Ikan Desa } \\
\text { Mina Jaya Desa Kalijaran ini adalah memberikan pengetahuan, pelatihan } \\
\text { dan pendampingan dalam memanfaatkan limbah budidaya ikan lele } \\
\text { dengan menggunakan sistem akuaponik untuk menghasilkan produk } \\
\text { pertanian berupa tanaman sayuran dan mengurangi pencemaran } \\
\text { lingkungan oleh limbah budidaya ikan lele tersebut. Kegiatan ini } \\
\text { mendapatkan tanggapan positif dari kelompok tani Ikan Mina Jaya Desa } \\
\text { Kalijaran. Hasil dari kegiatan pemberdayaan ini adalah kelompok tani ikan } \\
\text { Mina Jaya Desa Kalijaran menjadi faham dan mampu untuk membuat } \\
\text { instalasi sistem akuaponik dengan memanfaatkan limbah budidaya ikan } \\
\text { lele untuk mendapatkan tambahan hasil yaitu produk pertanian berupa } \\
\text { sayur-sayuran dan dapat mengurangi pencemaran lingkungan. }\end{array}$ \\
\hline
\end{tabular}

\section{Kata Kunci:}

Akuaponik

Ikan lele

Kelompok tani ikan

Mina Jaya

Limbah

Pemanfaatan

\section{ABSTRACT}

Fish farming group Mina Jaya Kalijaran village has potential in producing vegetables in the use of aquaponic system, this is because it is supported by abundant waste catfish cultivation. Utilization of catfish cultivation waste is still not maximized. Utilization of catfish cultivation by most members of fish farming group Mina Jaya Kalijaran village still has not led to produce agricultural products in the form of vegetables with aquaponic system. The aim of the empowerment activities of fish farming group Mina Jaya Kalijaran village is to provide knowledge, training and mentoring in utilizing the waste of catfish cultivation using the aquaculture system to produce agricultural products in the form of vegetables and reducing environmental pollution by the catfish cultivation waste. The activity received positive response from fish farming group of Mina Jaya Kalijaran village. The result of this empowerment activities is fish farming group Mina Jaya Kalijaran village become an undestand an able to make installation of aquaponic system by utilizing waste catfish farming to get additional results namely agricultural products in the form of and can reducing environmental pollution. 


\section{Pendahuluan}

Mata pencaharian penduduk di Desa Kalijaran adalah sebagai petani sawah dan petani ikan. Kelompok tani ikan Mina Jaya merupakan suatu perkumpulan pembudidaya ikan yang ada di Desa Kalijaran. Penggunaan kolam tanah atau kolam yang semula adalah sebidang sawah yang dialihfungsikan sebagai kolam ikan masih dimanfaatkan sebagai media untuk budidaya ikan. Akan tetapi, penggunaan kolam tanah memiliki sejumlah resiko yang berakibat kegagalan panen.

Salah satu penyebab kegagalan panen ikan adalah adanya kebocoran kolam yang diakibatkan oleh adanya hewan perusak yang sulit dikendalikan. Oleh karena itu, perlahan petani beralih untuk menggunakan kolam terpal sebagai media atau tempat untuk budidaya ikan. Kolam terpal menjadi media yang lebih praktis dan harga lebih ekonomis serta mudah dalam pemeliharaan ikan. Jenis ikan yang dibudidayakan oleh kelompok tani Mina Jaya adalah ikan gurame dan ikan lele. Budidaya ikan yang dilakukan oleh kelompok tani Mina Jaya Desa Kalijaran berupa pembesaran ikan, untuk saat ini jenis ikan yang banyak dibudidayakan adalah jenis ikan lele. Permintaan terhadap kebutuhan ikan lele sangat tinggi di masyarakat baik untuk konsumsi rumah tangga maupun untuk usaha.

Permasalahan utama kelompok tani ikan Mina Jaya Desa Kalijaran sebagai mitra kegiatan pengabdian kepada masyarakat ini adalah bahwa pada budidaya ikan lele yang dilakukan memberikan dampak pencemaran lingkungan yaitu berupa bau dan limbah budidaya ikan lele. Budidaya ikan lele menghasilkan amonia. Limbah budidaya ikan lele ini belum dimanfaatkan atau belum dikelola oleh kelompok tani ikan Mina Jaya di Desa Kalijaran, sehingga perlu untuk dilakukan kegiatan pendampingan terhadap kelompok tani Mina Jaya Desa Kalijaran untuk menambah pengetahuan dan keterampilan masyarakat dalam memanfaatkan limbah budidaya ikan lele yang sekaligus dapat menghasilkan produk pertanian menggunakan sistem akuaponik.

Sistem akuaponik merupakan sistem pertanian yang menggabungkan akuakultur dengan hidroponik. Bercocok tanam melalui sistem hidroponik memiliki banyak keuntungan mulai dari tempat, waktu dan tumbuhnya juga cepat [1]. Hidroponik dapat diaplikasikan baik sayuran maupun bunga [2][3]. Dalam sistem akuaponik memanfaatkan amonia yang dihasilkan oleh ikan lele hasil budidaya sebagai unsur hara yang bermanfaat untuk pertumbuhan dan perkembangan tanaman sayuran. Amonia di dalam kolam berasal dari protein yang terkandung pada

pakan ikan dan sisa metabolisme ikan, baik berupa feses maupun urin. Semakin tinggi $\mathrm{pH}$ dan suhu air kolam, semakin tinggi kadar amonia. Saat suhu dan pH tinggi, sebagian besar amonia akan diubah dalam bentuk NH3. Kadar amonia NH3 harus dikurangi agar tidak membunuh ikan dan tanaman [4].

Keuntungan lain dengan menggunakan sustem akuaponik dalam mengelola limbah budidaya ikan mitra juga mendapatkan tambahan hasil berupa produk pertanian berupa sayursayuran. Tanaman sayuran yang dibudidayakan adalah beberapa jenis tananam sayuran antara lain pakchoy, kaleo, kangkung, selada. Kegiatan pemanfaatan limbah budidaya ikan lele dilakukan dengan menggunakan sistem akuaponik. 


\section{METODOLOGI PENELITIAN}

Kegiatan pengabdian masyarakat di lakasanakan di Desa Kalijaran dengan mitra pengabdian adalah kelompok tani ikan Mina Jaya. Kegiatan dilaksanakan pada triwulan pertama sampai dengan akhir tahun 2019. Metode pelaksaanaan kegiatan pengabdian kepada masyarakat dengan mitra kelompok tani ikan Mina Jaya Desa Kalijaran dilakukan melalui kegiatan pemanfaatan limbah budidaya ikan lele dengan menggunakan sistem akuaponik. Permasalahan mitra terkait dengan pemanfaatan limbah budidaya ikan lele yang belum dilaksanakan oleh kelompok tersebut. Sehingga metode pelaksanaan yang dilakukan pada program ini meliputi :

1. Sosialisasi program

Sosialisasi program dilakukan kepada mitra yaitu kepada kepala desa dan ketua kelompok tani dengan tujuan untuk perizinan, pejelasan program, rencana pelaksanaan program

2. Pelatihan dan praktek instalasi sistem akuaponik

Kegiatan ini bertujuan untuk memberikan dasar pemikiran kepada mitra yaitu kelompok tani ikan Mina Jaya Desa Kalijaran tentang pemanfaatan limbah budidaya ikan lele menggunakan sistem akuaponik. Selanjutnya dilaksanakan praktek instalasi sistem akuaponik dengan memanfaatkan limbah budidaya ikan lele yang berasal dari kolam budidaya. Pelatihan dilakukan baik melalui materi tentang manfaat budidaya ikan serta pemanfaatan limbah ikan lele untuk kegiatan bercocok tanam dengan menggunakan sistem akuaponik berupa ceramah dan diskusi, pelatihan dan pendampingan ke kolam.

3. Pendampingan

Kegiatan pendampingan pada kelompok tani ikan Mina Jaya dilakukan setelah beberapa tahap dilaksanakan yaitu sosialisasi program dan pelatihan. Pendampingan dilakukan agar mendapatkan hasil sesuai dengan yang direncanakan yaitu mendapatkan hasil panen sayuran yang bagus. Pendampingan dilakukan dari awal pemeliharaan benih sampai dengan panen.

\section{HASIL DAN PEMBAHASAN}

\subsection{Tahapan Pelaksanaan Kegiatan Pengabdian Kepada Masyarakat}

Akuaponik adalah suatu metode menanam sayuran dan sejenisnya dengan memanfaatkan hasil kotoran ikan yang terbudidaya, tujuannya adalah untuk memelihara ikan dan sayuran dalam lingkungan yang terkontrol dan saling terintegrasi. Hasil dari kotoran atau sisa pakan yang berlebih merupakan nutrisi untuk proses pertumbuhan sayuran atau tanaman dan tanaman itu sendiri berfungsi sebagai filter kotoran, sehingga air yang keluar akan lebih bersih dibandingkan air yang masuk dari akuaponik [5].

Kegiatan pengabdian kepada masyarakat dilaksanakan dengan beberapa tahapan antara lain sosialisasi program, pelatihan dan praktek untuk menanam menggunakan sistem akuaponik, selain itu juga dilakukan pendampingan. Penjelasan program dilakukan dengan pemberian materi langsung oleh tim pengabdi. Kegiatan pengabdian kepada masyarakat ini mendapatkan apresiasi yang baik dari Kepala Desa dan khususnya dari kelompok tani ikan Mina Jaya dan mereka berharap ada keberlanjutan dari program pengabdian kepada masyarakat. Mitra yaitu kelompok tani ikan Mina Jaya antusias mengikuti program pengabdian kepada masyarakat dengan semangat untuk menghadiri, mengikuti kegiatan ini, 
komunikasi dua arah antara tim pengabdian dengan kelompok tani ikan Mina Jaya terjadi karena rasa keingintahuan dari kelompok tani dalam memanfaatkan limbah budidaya ikan lele yang selama ini hanya dibuang dan tidak dimanfaatkan sama sekali. Pelatihan dan praktek instalasi sistem akuaponik dilakukan dengan tujuan agar kelompok tani ikan Pokdakan Mina Jaya menjadi lebih fahan dan terampil dalam memanfaatkan limbah budidaya ikan lele untuk bertanam secara aquaponik. Berikut ini merupakan beberapa dokumentasi dari kegiatan program pengabdian kepada masyarakat :


Gambar 1. a. Persiapan pipa untuk hidroponik. b. Instalasi pipa untuk sistem akuaponik 
Bibit tanaman yang ditanam pada sistem akuaponik terlebih mengalami proses persemaian. Persemaian dilakukan dengan media tanam berupa rockwoll yang ditempatkan pada tray semai. Usia bibit tanaman yang siap dipindahkan kurang lebih 13 hari dari persemaian. Jenis tanaman yang digunakan pada sistem aquaponik ini adalah tanaman kangkung, pakchoy dan kaleo. Interaksi antara budidaya ikan dan tanaman yang dibudidayakan menghasilkan lingkungan yang sangat ideal untuk pertumbuhan sehingga lebih produktif dari metode tradisional. Pada sistem akuaponik tanaman dapat memanfaatkan bahan organik dari limbah budidaya lele untuk pertumbuhan sehingga dapat mengurangi zat-zat yang mencemari kolam ada pada air limbah budidaya ikan. Selanjutnya air kolam yang telah bersih dari zat pencemar dapat dimanfaatkan kembali untuk kegiatan pembudidayaan ikan lele [6].

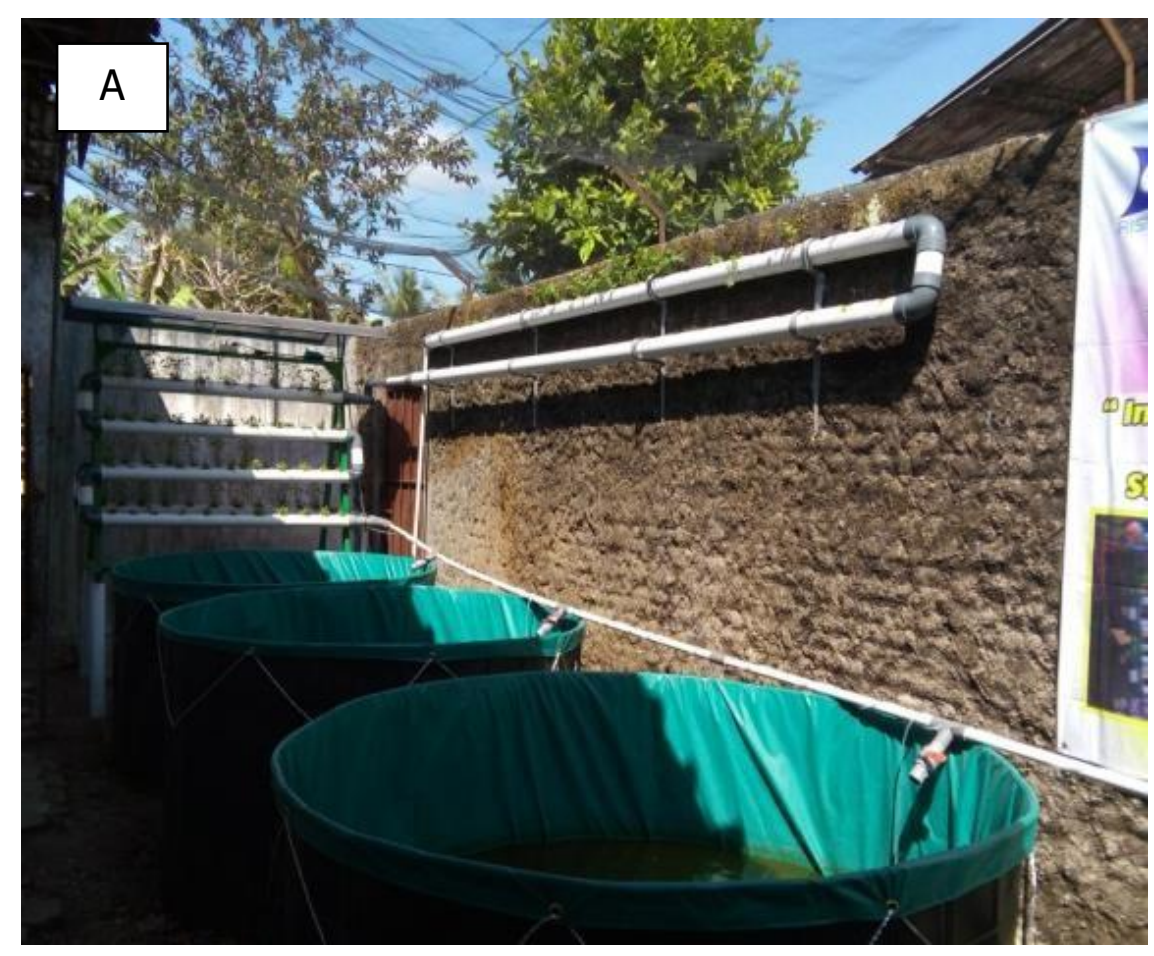




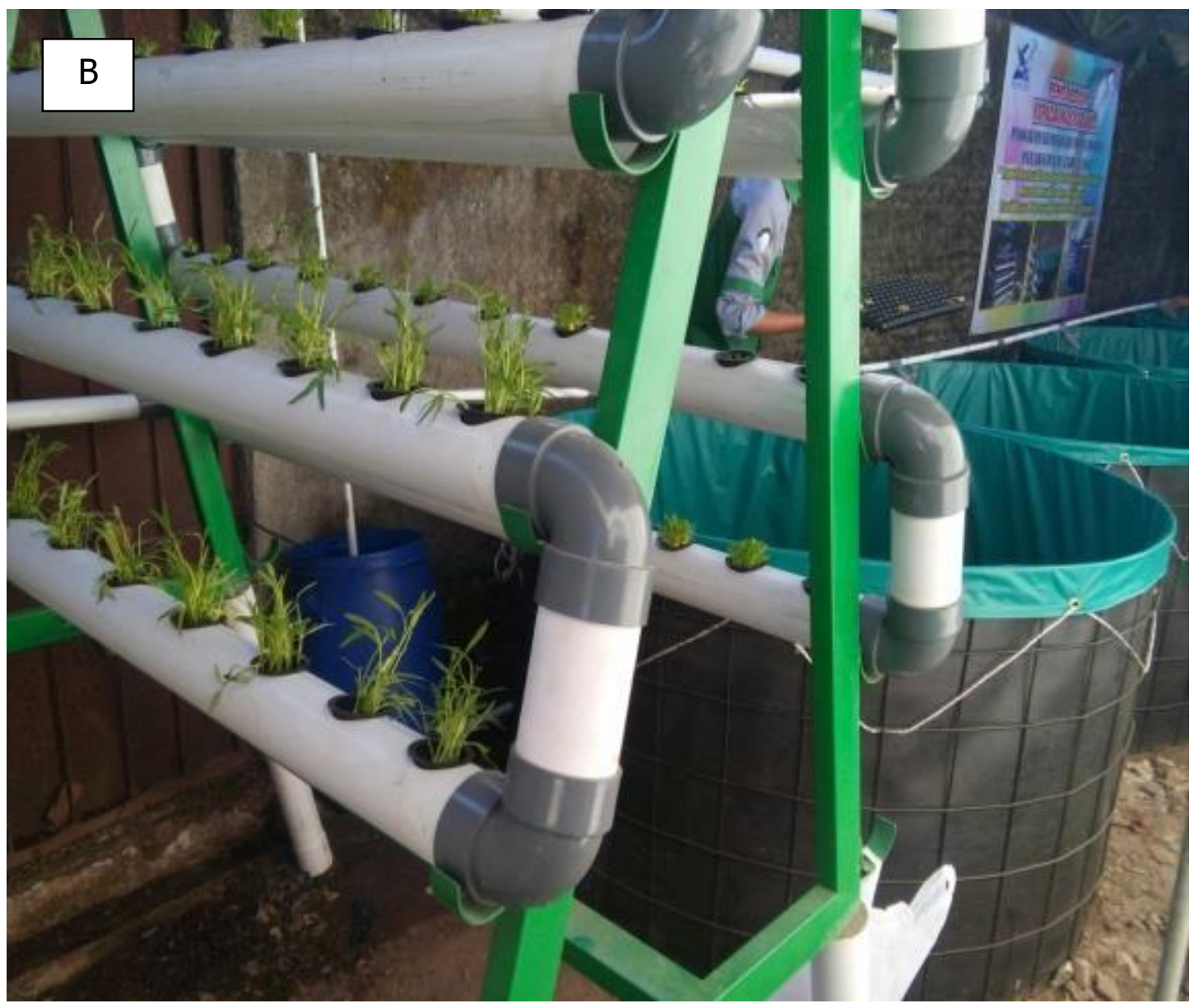

Gambar 2. a. Sistem akuaponik dengan memanfaatkan limbah budidaya ikan lele. b. Budidaya tanaman kangkung menggunakan sistem akuaponik

Hasil dari kegiatan pengabdian kepada masyarakat ini mendapat tanggapan positif dari mitra yaitu kelompok tani ikan Mina Jaya Desa Kalijaran. Kelompok tani menjadi faham dan terampil dalam pemanfaatan limbah budidaya ikan lele menggunakan sistem akuaponik untuk mengurangi pencemaran lingkungan yang berupa bau dan sekaligus mendapatkan tambahan hasil yang berupa produk pertanian berupa tanaman sayur- sayuran. 


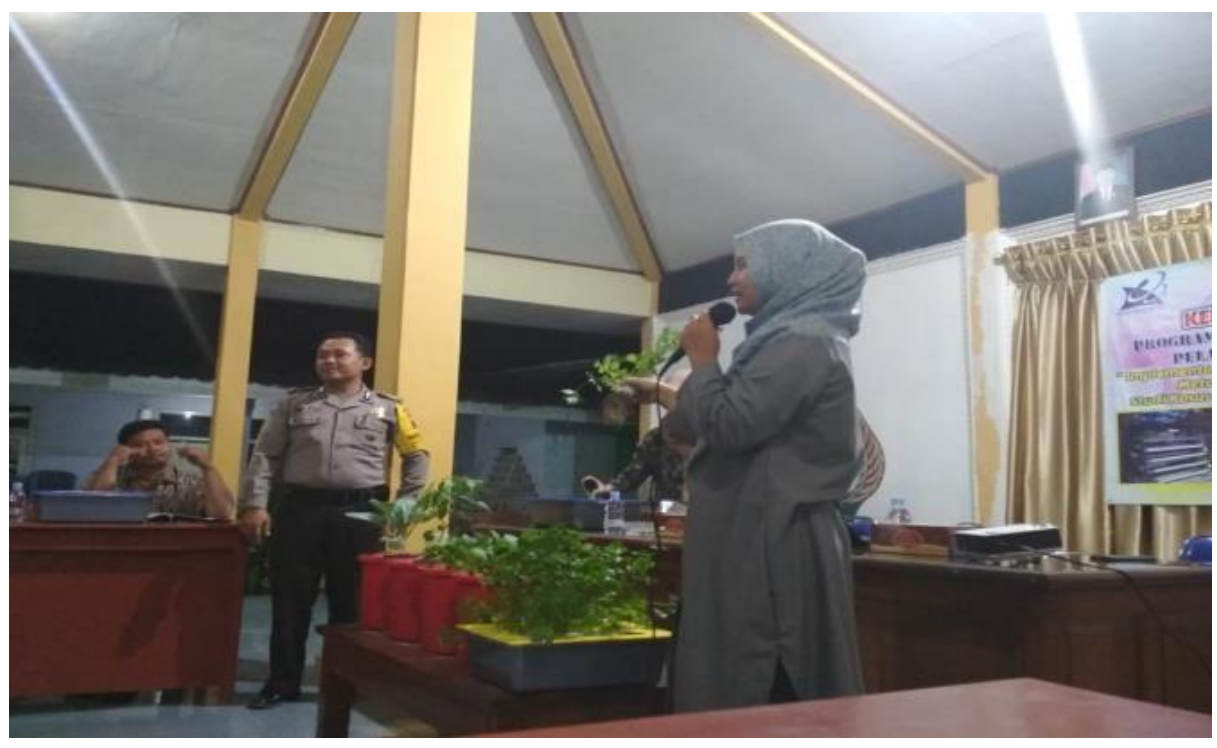

Gambar 3. Kegiatan Sosialisasi Program Pengabdian Kepada Masyarakat

\subsection{Kondisi Masyarakat Sebelum dan Sesudah Kegiatan Pengabdian Kepada Masyarakat}

Kelompok tani ikan Mina Jaya Desa Kalijaran membudidayakan ikan lele untuk mencukupi kebutuhan hidup sehari-hari. Selama ini kelompok tani ikan Mina Jaya membudidaya ikan dengan cara manual di kolam-kolam baik kolam tanah dan kolam terpal. Kemudahan dalam perawatan dan pemeliharaan ikan lele menjadikan kelompok tani ikan Mina Jaya beralih menggunakan kolam terpal untuk membudidayakan ikan lele. Pergantian air dilakukan kurang lebih \pm 3 minggu sekali apabila air dalam kolam sudah sangat pekat dan kurang baik untuk tanaman karena tidak mendapatkan sirkulasi sama sekali sehingga kotoran ikan dan amonia yang ada tetap berada di dalam kolam karena akan mengakibatkan pertumbuhan ikan terganggu.

Pergantian air dilakukan dengan membuang seluruh air yang ada di kolam ikan kemudian diganti dengan air yang masih jernih yang berasal dari sumber air yaitu sumur. Pergantian air menggunakan pompa air yang disedot dari dalam sumur dan membutuhkan waktu yang lama untuk mengisi kolam-kolam tersebut. Hal itu sebetulnya sangat disayangkan karena air limbah hasil budidaya ikan tersebut mengandung banyak nutrisi yang dibutuhkan oleh tanaman. Limbah budidaya ikan berasal dari kotoran yang dihasilkan oleh ikan maupun sisa pakan yang terdensap pada air tersebut.

Kegiatan pengabdian kepada masyarakat ini dilaksanakan dengan kegiatan pelatihan dan pendampingan ke kelompok tani ikan Mina Jaya Desa Kalijaran untuk memanfaatkan limbah hasil budidaya ikan lele yang diintegrasikan atau dikolaborasikan dengan kegiatan budidaya tanaman menggunakan sistem akuaponik. Air yang ada di dalam kolam dialirkan menggunakan pompa air ke dalam pipa-pipa instalasi sistem akuaponik. Air yang masuk ke dalam pipa-pipa instalasi akuaponik kandungan amonia dan nutrisi yang ada di dalam air tersebut diserap oleh akar-akar tanaman untuk mendukung pertumbuhan tanaman tersebut, sehingga air yang kembali ke dalam kolam kandungan amonia sudah berkurang.

Hal ini tentunya juga akan menghemat pengeluaran untuk kelompok tani ikan Mina Jaya Desa Kalijaran karena tidak mengeluarkan biaya untuk bahan bakar pompa air \pm 3 minggu 
sekali dan kelompok tani setelah adanya kegiatan ini dapat secara mandiri mempraktekkan keterampilan dalam budidaya tanaman dengan memanfaatkan limbah hasil budidaya ikan untuk kegiatan budidaya tanaman. Hasil budidaya tanaman sistem aquaponik menghasilkan sayuran yang organik karena sama sekali tidak menggunakan pupuk kimi dalam proses tanam sampai dengan hasil. Setelah kegiatan pengabdian masyarakat, kelompok tani ikan Mina Jaya dapat secara mandiri melaksanakan kegiatan budidaya ikan lele sekaligus menanam tanaman sayuran dengan sistem akuaponik dengan memanfaatkan limbah budidaya ikan lele.

\subsection{Kajian Kepuasan Masyarakat atas Kegiatan Pengabdian Kepada Masyarakat}

Kegiatan pengabdian kepada masyarakat dirasakan baik oleh kelmpok tani ikan Mina Jaya Desa Kalijaran. Kelompok tani ikan yang semula tidak memanfaatkan limbah hasil budidaya ikan, saat ini dapat memperoleh pengetahuan dan keterampilan dalam memanfaatkan limbah ikan lele. Kelompok tani ikan Mina Jaya sangat antusias dalam mengikuti setiap proses kegiatan pengabdian kepada masyarakat dari awal sampai akhir. Kelompok tani ikan Mina Jaya berharap semoga ada keberlanjutan dari program pengabdian kepada masyarakat sampai dengan pengemasan produk dan pemasaran, sehingga hasil dari bercocok tanam dapat dinikmati oleh skala luas.

\subsection{Kajian Kelayakan Finansial Investasi untuk Kelompok Tani Ikan Mina Mina Jaya}

Dari segi ekonomi, hasil dari kegiatan pengabdian kepada masyarakat ini sangat berkontribusi untuk menambah pendapatan dari kelompok tani. Hasil dari tanaman sayuran dapat dijual dalam skala kecil belum sampai ke pasar karena produksi yang masih sedikit, apabila kelompok tani ikan Mina Jaya dapat mengembangkan secara luas sistem akuaponik untuk masing-masing anggota dan nantinya ada pengepul untuk sayuran maka pendapat kelompok tani akan meningkat. Harga sayuran dengan sistem akuaponik dapat lebih mahal dibandingkan dengan sayuran dengan metode konvensional karena nutrisi yang dipakai untuk tanaman adalah organik. Minat masyarakat luas yang sadar akan kesehatan akan lebih memilih sayuran organik dibandingkan dengan sayuran dengan pupuk kimia. Dengan produksi yang banyak maka dengan sistem akuaponik yang memanfaatkan limbah ikan lele akan memberikan kontribusi yang baik dan banyak untuk kelompok tani ikan Mina Jaya Desa Kalijaran.

\section{KESIMPULAN}

Pelaksanaan kegiatan pengabdian kepada masyarakat pada kelompok tani ikan Mina Jaya Desa Kalijaran menjadi sarana untuk dapat meningkatkan pengetahuan dalam memanfaatkan limbah budidaya ikan lele dengan sistem akuaponik sehingga dapat menghasilkan produk pertanian berupa sayur-sayuran. Kegiatan pelatihan dapat berjalan sesuai dengan harapan dan target yaitu mitra faham dan mampu membuat sistem akuaponik untuk memanfaatkan limbah budidaya ikan lele. Melalui kegiatan ini kelompok tani ikan Mina Jaya Desa Kalijaran mendapatkan ilmu baru dalam mengelola limbah budidaya ikan yang dapat dimanfaatkan untuk kegiatan pertanian. Saran dari kegiatan pengabdian ini adalah kegiatan ini sebaiknya dilanjutkan sampai dengan pemasaran produk pertanian organik yang tentunya akan lebih mendapatkan nilai jual yang tinggi dibandingkan dengan produk konvensional (bukan organik). 
Akuaponik sebagai Sistem Pemanfaatan Limbah Budidaya Ikan Lele di Desa Kalijaran

\section{REFERENSI}

[1] Edwardi. 2017. Inilah Manfaat Bercocok Tanam Hidroponik. Bangka Pos. Retrieved from https://bangka.tribunnews.com/2017/04/01/inilah-manfaat-bercocok-tanamhidroponik . diakses tanggal 2 Juli 2019.

[2] Sulistyawati, dkk. 2019. Pendampingan Pembuatan Sistem Hidroponik dan Pengolahan Sampah Organik. Jurnal Pengabdian dan Pemberdayaan Masyarakat. Volume 3 (1) : 77-82.

[3] Wijayanto, H. 2019. Pemberdayaan Kelompok Tani Desa Jatimalang, Kabupaten Pacitan melalui Pelatihan Pembuatan Pupuk Organik. Agrokreatif Jurnal Ilmiah Pengabdian Kepada Masyarakat. Vol 5 (2) : 109-114.

[4] Habiburrohman. 2018. Aplikasi Teknologi Akuaponik Sederhana Pada Budidaya Ikan Air Tawar Untuk Optimalisasi Pertumbuhan Tanaman Sawi (Brassica juncea L.) Skripsi. Fakultas Tarbiyah dan Keguruan. Universitas Islam Negeri Raden Inten Lampung.

[5] Marsela, F. (2018). Sistem Akuaponik Dengan Limbah Kolam Ikan Lele Untuk Memproduksi Sayuran Organik. Skripsi. Fakultas Pertanian. Universitas Lampung. Bandar Lampung

[6] Mandala., A. P. 2017. Pemanfaatan Air Limbah Kolam Lele untuk Budidaya Azolla mycrophylla. Skripsi. Fakultas Pertanian. Universitas Lampung. Bandar Lampung. 
Murni Handayani, Cahya Vikasari, Oto Prasadi 